Click www.researchjournal.co.in/online/subdetail.html to purchase.

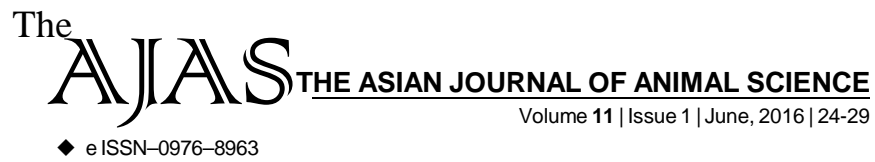

DOI : 10.15740/HAS/TAJAS/11.1/24-29 Visit us | www.researchjournal.co.in $\mathbf{S}$

RESEARCH ARTICLE.

\title{
Effect of different colours of light on performance of caged broilers
}

\author{
HARISH KUMAR MAURYA, KULADIP PRAKASH SHINDE, RAMESH PANDEY AND SHAILESH \\ KUMAR GUPTA
}

Author for Corresponding -

KULADIP PRAKASH SHINDE

Division of Livestock Production and Management, ICAR-National

Dairy Research Institute,

KARNAL (HARYANA) INDIA

Email: kuls164@gmail.com

See end of the article for

Coopted authors'
ABSTRACT...... The objective of this study was to evaluate the performance of the broiler chicken (body weight, feed intake and feed conversion ratio) at the fifth week of age. The broiler chicks were weighed, leg banded and distributed randomly into four groups as treatments, battery type iron cages, feeders, waters and other equipments were thoroughly cleaned disinfected, dried, sterilized by blow torch and finally fumigated by use of mixture of $\mathrm{KMnO}_{4}$ (potassium permanganates) and formaldehyde before use. The chicks were fed ad libitum with standard starter ration containing CP: 22 per cent and ME:2900 k.cal./kg feed upto 3 weeks age and then after broiler finisher ration with CP: 19 per cent and ME: 3000 k.cal./ $\mathrm{kg}$ feed upto 5 weeks age. The broiler chicks of all groups were kept under similar management practices except lighting regimes as per treatment upto five (5) weeks age in battery type iron cages in laboratory. It is concluded colours of light did not show any significant effect on feed intake and feed conversion ratio (FCR) in broilers. The colour of light has a significant effect on the weight gain at the fifth week of age. The milky white and yellow colours of light are effective to obtain higher weekly body weight at five weeks age of caged broilers.

KEY WORDS....... Broiler, Growth rate, Body weight, Colour, Light

HOW TO CITE THIS ARTICLE - Maurya, Harish Kumar, Shinde, Kuladip Prakash, Pandey, Ramesh and Gupta, Shailesh Kumar (2016). Effect of different colours of light on performance of caged broilers. Asian J. Animal Sci., 11(1): 24-29 (DOI : 10.15740/HAS/TAJAS/11.1/24-29).

ARTICLE CHRONICLE - Received : 07.03.2016; Revised : 21.04.2016; Accepted : 13.05.2016 